\title{
MENINGKATKAN KEMAMPUAN SISWA PADA KONSEP MEMECAHKAN PERMASALAHAN DAMPAK TEKNOLOGI LEWAT DISKUSI MELALUI MODEL PEMBELAJARAN KOOPERATIF TIPE BERPIKIR-BERPASANGAN-BERBAGI KELAS VIII MTSN 2 BATANG ALAI SELATAN
}

\author{
Akhlakul Karimah dan Irni Cahyani \\ STKIP PGRI Banjarmasin
}

\begin{abstract}
Abstrak
Metode penelitian yang digunakan adalah metode deskriptif dengan bentuk penelitian tindakan kelas. Teknik pengumpulan data digunakan tes tertulis pada akhir siklus, observasi kegiatan pembelajaran guru, observasi kegiatan siswa, dan angket respons siswa terhadap pembelajaran. Analisis data yang digunakan berdasarkan penghitungan distribusi frekuensi dengan pembahasan berdasarkan skala presentase dan indikator ketuntasan belajar yang ditetapkan kurikulum.

Berdasarkan penelitian dapat disimpulkan, (1) penerapan model pembelajaran kooperatif tipe berpikir-berpasangan-berbagi dapat meningkatkan kemampuan siswa dalam berdiskusi. Hal ini dibuktikan oleh rata-rata nilai individu pada siklus I pertemuan 1 yaitu 75,2, meningkat pada siklus I pertemuan 2 menjadi 78,66. Pada siklus II pertemuan 1 yaitu 80,33, sedangkan pada siklus II pertemuan 2 mengalami peningkatan yaitu 90 , (2) terdapat peningkatan aktivitas belajar guru dan siswa dalam menulis teks diskusi menggunakan model pembelajaran kooperatif tipe berpikirberpasangan-berbagi dilihat dari peningkatan aktivitas setiap pertemuan, (3) respons siswa kelas VIII C MTsN 2 Batang Alai Selatan Kabupaten Hulu Sungai Tengah mengalami peningkatan secara positif terhadap pembelajaran teks diskusi menggunakan model pembelajaran kooperatif tipe berpikir-berpasangan-berbagi.
\end{abstract}

\section{PENDAHULUAN}

Proses pembelajaran yang dapat memberikan pengalaman secara langsung kepada siswa, menuntut guru untuk dapat memfasilitasi terjadinya proses aktif siswa dalam belajar melalui berbagai variasi kegiatan belajar, maupun penggunaan metode pembelajaran yang sesuai. Dengan demikian, proses pembelajaran yang terlaksana diharapkan dapat membantu peserta didik dalam mengembangkan segenap potensi yang dimilikinya. Hal ini sesuai dengan konsep pembelajaran dalam kurikulum 2013 yang berlaku saat ini. Model pembelajaran dalam kurikulum 2013 adalah suatu perencanaan atau suatu pola yang digunakan sebagai pedoman dalam merencanakan pembelajaran di kelas atau pembelajaran dalam tutorial dan untuk menentukan perangkat-perangkat pembelajaran termasuk di dalamnya buku-buku, film, komputer, kurikulum, dan lain-lain.

Pada kurikulum 2013 dinyatakan, bahwa pembelajaran bahasa Indonesia di SMP/MTs berorientasi pada kedudukan bahasa Indonesia sebagai bahasa nasional dan bahasa negara. Hakikat pembelajaran bahasa harus dilaksanakan di SMP/MTs, termasuk dalam konteks penelitian ini. Hal ini patut disadari secara penuh, terutama oleh guru yang bertugas dan bertanggung jawab membelajarkan siswa di SMP//MTs yang menjadi subjek (pelaku) dalam penelitian ini. 
Belajar merupakan suatu proses yang dilakukan seseorang untuk memperoleh suatu perubahan yang baru secara keseluruhan sebagai hasil pengalamannya sendiri dalam interaksi dengan lingkungannya. Tingkat keberhasilan pendidikan tidak terlepas dari proses belajar dan pembelajaran yang dilakukan oleh siswa.

Masalah yang dihadapi oleh siswa dalam proses belajar mengajar yaitu kesulitan siswa dalam memahami materi yang diajarkan guru dengan menggunakan model pembelajaran yang belum mengaktifkan seluruh siswa dalam aktivitas pembelajaran yang sangat kecil, karena kegiatan pembelajaran didominasi oleh siswa yang memiliki kemampuan tinggi, sementara siswa yang memiliki kemampuan rendah hanya menonton saja (pasif). Hal ini berarti dalam suatu kelompok belajar masih banyak siswa yang belum melakukan keterampilan kooperatif. Hal ini menyebabkan sebagian besar siswa terutama yang memiliki kemampuan rendah enggan berpikir, sehingga timbul perasaan jenuh dalam mengikuti pelajaran bahasa Indonesia akibat dari sikap siswa tersebut, maka hasil belajarpun kurang memuaskan, dalam arti tidak memenuhi batas tuntas yang ditetapkan di sekolah.

Setiap kegiatan pembelajaran bahasa Indonesia, guru sering dihadapkan pada permasalahan bahwa hasil belajar siswa kurang memuaskan, berdasarkan hasil dialog dengan guru bahasa Indonesia kelas VIII di MTsN 2 Batang Alai Selatan diperoleh informasi bahwa sebagian besar siswa kurang aktif di kelas yang ditunjukkan oleh beberapa hal yaitu: siswa kurang aktif bertanya kepada guru, kurang berinteraksi dengan siswa lain, siswa sulit mengajukan pendapat, serta kurangnya minat dan perhatian siswa terhadap kegiatan pembelajaran. Keadaan tersebut menyebabkan sebagian besar siswa mengalami kesulitan dalam pemecahan masalah ataupun soal yang diberikan oleh guru, sehingga hasil belajar siswa pada materi teknologi lewat diskusi adalah Model Pembelajaran Kooperatif Tipe Berpikir-Berpasangan-Berbagi.

(Berpikir-Berpasangan-Berbagi) merupakan jenis pembelajaran kooperatif yang dirancang untuk mempengaruhi pola interaksi siswa. Berpikir-berpasangan-berbagi menghendaki siswa bekerja saling membantu dalam kelompok kecil (2-6 anggota) dan lebih dirincikan oleh penghargaan kooperatif daripada penghargaan individual (Ibrahim Dkk: 2000: 3).

Model Berpikir-Berpasangan-Berbagi tumbuh dari penelitian pembelajaran kooperatif, Model Berpikir-Berpasangan-Berbagi dapat juga disebut sebagai model belajar-mengajar berpasangan. Model ini pertama kali dikembangkan oleh Frank Lyman dari Universitas Maryland pada tahun 1985 (Think-Pair-Share) sebagai struktur kegiatan pembelajaran gotong royong. Model ini memberikan siswa kesempatan untuk bekerja sendiri serta bekerjasama dengan orang lain. Berpikirberpasangan-berbagi memiliki prosedur yang ditetapkan secara eksplisit untuk memberi siswa waktu lebih banyak untuk berpikir, menjawab, dan saling membantu satu sama lain. Model Pembelajaran Berpikir-Berpasangan-Berbagi sebagai ganti dari tanya jawab seluruh kelas. 
Oleh karena itu, dengan menerapkan model pembelajaran tersebut siswa diharapkan dapat saling membantu dalam menyelesaikan masalah, saling menyampaikan pendapat, dan lebih aktif dalam berinteraksi, serta dapat meningkatkan penguasaan materi terhadap konsep memecahkan permasalahan dampak teknologi lewat diskusi.

Berdasarkan latar belakang masalah di atas, maka perlu kiranya diadakan suatu penelitian untuk mencari alternatif pemecahan masalah pembelajaran, khususnya pada materi memecahkan permasalahan dampak teknologi lewat diskusi. Adapun judul yang diangkat dalam penelitian ini adalah "Meningkatkan Kemampuan Siswa pada Konsep Memecahkan Permasalahan Dampak Teknologi Lewat Diskusi melalui Model Pembelajaran Kooperatif Tipe Berpikir-BerpasanganBerbagi Siswa Kelas VIII MTsN 2 Batang Alai Selatan.”

\section{Kajian Teori}

Model Pembelajaran Berpikir-Berpasangan-Berbagi menggunakan metode diskusi berpasangan yang dilanjutkan dengan diskusi pleno. Dengan model pembelajaran ini siswa dilatih bagaimana mengemukakan pendapat dan siswa juga belajar menghargai pendapat orang lain dengan tetap mengacu pada materi/tujuan pembelajaran.(Ibrahim, Dkk,2000: 5).

Berpikir-berpasangan-berbagi merupakan suatu teknik sederhana dengan keuntungan besar. Berpikir-berpasangan-berbagi dapat meningkatkan kemampuan siswa dalam mengingat suatu informasi dan seorang siswa juga dapat belajar dari siswa lain serta saling menyampaikan idenya untuk didiskusikan sebelum disampaikan di depan kelas. Selain itu, berpikir-berpasangan-berbagi juga dapat memperbaiki rasa percaya diri dan semua siswa diberi kesempatan untuk berpartisipasi dalam kelas. Berpikir-Berpasangan-Berbagi sebagai salah satu metode pembelajaran kooperatif yang terdiri dari 3 tahapan, yaitu berpikir, berpasangan, berbagi. Guru tidak lagi sebagai satusatunya sumber pembelajaran (Teacher Oriented), tetapi justru siswa dituntut untuk dapat menemukan dan memahami konsep-konsep baru (Student Oriented). (Ibrahim, Dkk, 2000: 5).

Kelebihan Model Pembelajaran Kooperatif Tipe Berpikir-Berpasangan-Berbagi antara lain sebagai berikut.(Ibrahim, Dkk, 2000: 6).

1. Memberikan lebih banyak waktu kepada siswa untuk berpikir dan saling membantu dalam menuntaskan materi, sehingga dapat meningkatkan hasil belajar siswa.

2. Membantu meningkatkan hubungan yang positif di antara siswa, juga secara bersamaan dapat meningkatkan kemampuan akademik siswa.

Kelemahan Model Pembelajaran Kooperatif Berpikir-Berpasangan-Berbagi antara lain sebagai berikut.(Ibrahim, Dkk, 2000: 18).

1. Memerlukan biaya dan waktu yang relatif banyak. 
2. Apabila banyak siswa dalam kelas sangat besar, maka guru akan kesulitan dalam membimbing siswa secara keseluruhan.

Dengan demikian, guru dapat mengurangi kelemahan yang terdapat dalam setiap model pembelajaran yang akan diterapkan di dalam kelas.

Dapat diketahui bahwa setiap model pembelajaran memiliki kelebihan dan kelemahan dalam setiap penerapannya. Oleh karena itu, guru harus dapat mengetahui hal tersebut, serta menggunakan model pembelajaran yang akan digunakan ketika pada saat pembelajaran, karena akan berpengaruh pada kegiatan belajar mengajar.

Ciri utama pada Model Pembelajaran Kooperatif Tipe Berpikir-Berpasangan-Berbagi adalah tiga langkah utamanya yang dilaksanakan dalam proses pembelajaran. Yaitu langkah berpikir (berpikir secara individual), berpasangan (berpasangan dengan teman sebangku),dan berbagi (berbagi jawaban dengan pasangan lain atau seluruh kelas).(Ibrahim, Dkk, 2006: 26-27).

1. Berpikir (berpikir secara individual)

Pada tahap berpikir, guru mengajukan suatu pertanyaan atau masalah yang dikaitkan dengan pelajaran, dan siswa diminta untuk berpikir secara mandiri mengenai pertanyaan atau masalah yang diajukan. Pada tahapan ini, siswa sebaiknya menuliskan jawaban mereka, Hal ini karena, guru tidak dapat memantau semua jawaban siswa sehingga melalui catatan tersebut guru dapat mengetahui jawaban yang harus diperbaiki atau diluruskan di akhir pembelajaran. Dalam menentukan batasan waktu untuk tahap ini, guru harus mempertimbangkan pengetahuan dasar siswa untuk menjawab pertanyaan yang diberikan, jenis dan bentuk pertanyaan yang diberikan, serta jadwal pembelajaran untuk setiap kali pertemuan.

Kelebihan dari tahap ini adalah adanya waktu berpikir yang memberikan kesempatan kepada siswa untuk berpikir mengenai jawaban mereka sendiri sebelum pertanyaan tersebut dijawab oleh siswa lain. Selain itu, guru dapat mengurangi masalah dari adanya siswa yang mengobrol, karena tiap siswa memiliki tugas untuk dikerjakan sendiri.

2. Berpasangan (berpasangan dengan teman sebangku)

Langkah kedua adalah guru meminta para siswa untuk berpasangan dan mendiskusikan mengenai apa yang telah dipikirkan. Interaksi selama periode ini dapat menghasilkan jawaban bersama. Biasanya guru mengizinkan tidak lebih dari 4 atau 5 menit untuk berpasangan. Setiap pasangan siswa saling berdiskusi mengenai hasil jawaban mereka sebelumnya sehingga hasil akhir yang didapat menjadi lebih baik, karena siswa mendapat tambahan informasi dan pemecahan masalah yang lain.

3. Berbagi (berbagi jawaban dengan pasangan lain atau seluruh kelas)

Pada langkah akhir ini guru meminta pasangan-pasangan tersebut untuk berbagi hasil pemikiran mereka dengan pasangan lain atau dengan seluruh kelas. Pada langkah ini akan 
menjadi efektif jika guru berkeliling kelas dari pasangan satu ke pasangan yang lain, sehingga seperempat atau separuh dari pasangan-pasangan tersebut memperoleh kesempatan untuk melapor. Langkah ini merupakan penyempurnaan dari langkah-langkah sebelumnya, dalam arti bahwa langkah ini menolong agar semua kelompok menjadi lebih memahami mengenai pemecahan masalah yang diberikan berdasarkan penjelasan kelompok yang lain. Hal ini juga agar siswa benar-benar mengerti ketika guru memberikan koreksi maupun penguatan di akhir pembelajaran.

Model Pembelajaran Kooperatif Tipe Berpikir-Berpasangan-Berbagi

- Guru mengajarkan materi seperti biasa, alat peraga disarankan.

- $\quad$ Dengan tanya jawab, guru memberikan contoh soal.

- Guru memberikan soal yang dikerjakan siswa berdasar persyaratan soal sebagai problem.

- Siswa dipandu guru untuk menyelesaikan soal.

- $\quad$ Guru memimpin pleno kecil diskusi, tiap kelompok mengemukakan hasil diskusinya.

- Berawal dari kegiatan tersebut mengarahkan pembicaraan pada pokok permasalahan dan menambah materi yang belum diungkapkan para siswa.

- $\quad$ Guru menutup kesimpulan.

- $\quad$ Penutup. (Amri,Sofan, 2012:11).

Tujuan-tujuan pembelajaran ini mencakup tiga jenis tujuan penting, yaitu hasil belajar akademik, penerimaan terhadap keragaman, dan pengembangan keterampilan sosial. (Ibrahim, Dkk, 2000: 7). Pembelajaran Kooperatif mempunyai efek yang berarti terhadap permainan yang luas terhadap keragaman ras, budaya dan agama, strata sosial, kemampuan dan ketidakmampuan. (Ibrahim, Dkk, 2000: 9).

Pembelajaran Kooperatif memberikan peluang kepada siswa yang berbeda latar belakang dan kondisi untuk bekerja saling bergantung satu sama lain atas tugas-tugas bersama dan mulai penggunaan struktur penghargaan kooperatif, belajar untuk menghargai satu sama lain. Keterampilan sosial atau kooperatif berkembang secara signifikan dan pembelajaran Kooperatif sangat tepat digunakan untuk melatihkan keterampilan-keterampilan kerjasama dan kolaborasi, dan juga keterampilan-keterampilan tanya jawab. (Ibrahim, Dkk, 2000: 9).

Untuk mendapat hasil yang optimal dari penerapan Model Pembelajaran Tipe BerpikirBerpasangan-Berbagi ini maka seorang guru dapat menempuh tahapan pembelajaran sebagai berikut.(Ibrahim, Dkk, 2000: 29)

a. Guru menentukan suatu pokok bahasan yang akan disajikan kepada siswanya dengan mengadopsi Model Pembelajaran Berpikir-Berpasangan-Berbagi.

b. Guru menjelaskan kepada seluruh siswa tentang akan diterapkannya Model Pembelajaran Berpikir-Berpasangan-Berbagi, sebagai suatu variasi model pembelajaran. 
c. Guru menyiapkan materi bahan ajar yang harus dikerjakan kelompok.

d. Guru membentuk kelompok-kelompok kecil dengan anggota 2-4 siswa. Kelompok dibuat heterogen tingkat kepandaiannya dengan mempertimbangkan keharmonisan kerja kelompok.

e. Guru menjelaskan materi baru secara singkat, kemudian memberikan soal latihan dalam bentuk Lembar Kerja Siswa.

f. Siswa diminta untuk mengerjakan soal secara mandiri untuk beberapa saat.

g. Siswa mendiskusikan hasil pemikirannya sendiri dengan pasangannya, sehingga didapatkan jawaban soal yang merupakan hasil diskusi dalam pasangan yang nantinya akan digunakan sebagai bahan berbagi/sharing dengan kelompoknya.

h. Guru memberi kesempatan kepada kelompok untuk melaporkan hasil diskusinya di depan kelas, diikuti dengan kelompok lain yang memperoleh hasil yang berbeda sehingga terjadi proses berbagi/sharing pada diskusi kelas.

i. Guru memberikan kesimpulan akhir dari diskusi kelas.

j. Menjelang akhir waktu, guru memberikan latihan pendalaman secara klasikal dengan menekankan strategi pemecahan masalah.

k. Guru merefleksi hasil kegiatan belajar bersama siswa.

1. Guru dapat memberikan tes formatif, sesuai dengan Indikator/kompetensi yang ditentukan.

Ciri-ciri pembelajaran kooperatif adalah sebagai berikut.

1. Siswa belajar dalam kelompok secara kooperatif untuk menuntaskan materi belajarnya.

2. Kelompok dibentuk dari siswa yang memiliki kemampuan heterogen tinggi, sedang dan rendah).

3. Bilamana mungkin, anggota kelompok dari ras, budaya, suku, jenis kelamin yang berbedabeda.

4. Penghargaan lebih berorientasi kelompok dari pada individu. (Ibrahim, dkk, 2000: 6).

Dilihat dari unsur-unsur dan ciri-ciri yang ada dalam pembelajaran kooperatif sangat berguna. Untuk membantu siswa menumbuhkan kemampuan kerja sama, berpikir, kritis dan kemampuan untuk membantu teman.

Agar pembelajaran Kooperatif dapat berjalan efektif, maka perlu ditanamkan unsur-unsur dasar pembelajaran kooperatif yaitu:

1. Siswa harus memiliki persepsi bahwa mereka "sehidup sepenanggungan bersama".

2. Siswa bertanggungjawab atas segala sesuatu di dalam kelompoknya seperti Miliknya sendiri.

3. Siswa harus melihat bahwa semua anggota di dalam kelompoknya memiliki Tujuan yang sama. 
4. Siswa haruslah membagi tugas dan tanggung jawab yang sama di antara anggota kelompoknya.

5. Siswa akan dikenakan evaluasi atau diberikan hadiah / penghargaan yang akan juga dikenakan untuk semua anggota kelompok.

6. Siswa akan berbagi kepemimpinan mereka dan mereka membutuhkan keterampilan untuk belajar bersama selama proses belajarnya.

7. Siswa akan diminta mempertanggung jawabkan secara individu materi yang ditangani dalam kelompok kooperatif. (Ibrahim, Dkk, 2000:6).

\section{METODE PENELITIAN}

Penelitian direncanakan berlangsung 2 siklus dan kedua siklus dilaksanakan dalam 2 kali pertemuan. Penelitian dilaksanakan dalam bentuk siklus, yang dimana setiap siklus dilaksanakan melalui 4 tahapan pokok, yaitu: 1) Perencanaan 2) Pelaksanaan 3) Observasi 4) Refleksi.

Subjek penelitian yang digunakan dalam penelitian ini adalah siswa kelas VIII MTsN 2 Batang Alai Selatan dengan jumlah 21 orang siswa laki-laki. Penelitian ini dilaksanakan di MTsN 2 Batang Alai Selatan yang beralamat di Desa Rangas Kecamatan Batang Alai Selatan Kabupaten Hulu Sungai Tengah. Waktu penelitian ini dilaksanakan pada semester II Tahun Pelajaran 2017 dan berlangsung selama 1 bulan dari bulan April sampai bulan Mei.

Penelitian ini menggunakan 5 metode pengumpulan data, yaitu metode observasi, diskusi, wawancara, tes, dan angket. Teknik analisis data yang digunakan dalam penelitian ini meliputi: Analisis Kuantitatif dan Analisis Kualitatif.

\section{HASIL DAN PEMBAHASAN}

Penelitian tindakan kelas ini dilaksanakan di MTsN 2 Batang Alai Selatan Kabupaten Hulu Sungai Tengah dengan menggunakan Model Pembelajaran Kooperatif Tipe Berpikir-BerpasanganBerbagi. Kelas yang menjadi subjek penelitian adalah kelas VIII C dengan jumlah 21 orang lakilaki. Penelitian ini dilaksanakan dalam dua siklus. Setiap siklus terdiri atas dua kali pertemuan.

Kegiatan belajar mengajar bahasa Indonesia kelas VIII C MTsN 2 Batang Alai Selatan dalam menulis teks diskusi dengan penggunaan Model Pembelajaran Kooperatif Tipe BerpikirBerpasangan-Berbagi berhasil dengan baik. Peningkatan keberhasilan tersebut dapat kita ketahui melalui kemampuan hasil belajar siswa, aktivitas guru, aktivitas siswa, dan respons siswa. Keberhasilan dalam pembelajaran bahasa Indonesia dengan menggunakan Model Pembelajaran Kooperatif Tipe Berpikir-Berpasangan-Berbagi pada materi teks diskusi dapat dijabarkan sebagai berikut. 
Berdasarkan data yang diperoleh pada pelaksanaan penelitian tindakan kelas dapat dipaparkan data mengenai hasil belajar siswa pada setiap siklus sebagai berikut.

Tabel 4.18 Perbandingan Hasil Belajar Siklus I dan II.

\begin{tabular}{|c|c|c|c|c|}
\hline \multicolumn{2}{|c|}{ Siklus I } & \multicolumn{2}{c|}{ Siklus II } & \multirow{2}{*}{ Keterangan } \\
\cline { 1 - 3 } Pertemuan I & Pertemuan II & Pertemuan I & Pertemuan II & \\
\hline 75,2 & 78,66 & 80,33 & 90 & Rata-rata \\
\hline $85,71 \%$ & $90,48 \%$ & $95,24 \%$ & $100 \%$ & Ketuntasan \\
\hline
\end{tabular}

Pada siklus I pertemuan 1 rata-rata yaitu 75,2 dengan ketuntasan deksriptif $85,71 \%$. Jumlah nilai seluruh siswa yaitu 1580. Jadi nilai rata-rata kelas adalah 80. Dengan kriteria ketuntasan minimal 70, maka dapat disimpulkan bahwa sebagian besar siswa belum tuntas ada 3 orang atau sekitar $14,29 \%$. Sedangkan siswa yang tuntas adalah 18 orang atau $85,71 \%$. Pada siklus I pertemuan 2 rata-rata yaitu 78,66 dengan ketuntasan deksriptif 90,48\%.

Hasil belajar siswa pada siklus II pertemuan 1 ini, sudah mencapai ketuntasan secara deskriptif yaitu 95,24\%, dan nilai rata-rata siswa mencapai 80,33. pada siklus II pertemuan 2 dapat diketahui bahwa diperoleh nilai rata-rata sebesar 90 dengan tingkat ketuntasan 100\% siswa telah tuntas belajar.

Penerapan Model Pembelajaran Berpikir-Berpasangan-Berbagi dapat mengembangkan keterampilan berpikir dan menjawab dalam komunikasi antara satu dengan yang lain, serta bekerja saling membantu dalam kelompok kecil.

Dalam hal ini, guru sangat berperan penting untuk membimbing siswa melakukan diskusi, sehingga terciptanya suasana belajar yang lebih hidup, aktif, kreatif, efektif dan menyenangkan.

Dengan demikian jelas bahwa melalui Model Pembelajaran Berpikir-Berpasangan-Berbagi, siswa secara langsung dapat memecahkan masalah, memahami suatu materi secara berkelompok dan saling membantu antara satu dengan yang lainnya, membuat kesimpulan (diskusi) serta mempresentasikan di depan kelas sebagai salah satu langkah evaluasi terhadap kegiatan pembelajaran yang telah dilakukan. Model Pembelajaran kooperatif merupakan model pembelajaran yang mengutamakan kerjasama diantara siswa untuk mencapai tujuan pembelajaran.

Aktivitas Siswa dan Guru mengalami peningkatan setiap kali pertemuan pada proses belajar mengajar berjalan dengan lancar dan efektif, siswa lebih aktif dalam mengikuti pembelajaran.

Hasil respon peserta didik terhadap pembelajaran menggunakan Model Pembelajaran Kooperatif Tipe Berpikir-Berpasangan-Berbagi merupakan sebuah pengalaman proses pembelajaran yang telah dilaksanakan mulai siklus I sampai siklus II dengan 4 kali pertemuan. Hal ini terbukti dari respon positif siswa kelas VIII C MTsN 2 Batang Alai Selatan Kabupaten Hulu Sungai Tengah terhadap pembelajaran menulis teks diskusi dengan menggunakan Model Pembelajaran Kooperatif Tipe Berpikir-Berpasangan-Berbagi. 


\section{A. Kesimpulan}

Berdasarkan hasil penelitian dan pembahasan, maka dapat disimpulkan pembelajaran Kooperatif Tipe Berpikir-Berpasangan-Berbagi lebih efektif dan siswa lebih aktif dalam mengikuti pembelajaran.

1. Penggunaan Model Pembelajaran Kooperatif Tipe Berpikir-Berpasangan-Berbagi dapat meningkatkan kemampuan siswa kelas VIII C MTsN 2 Batang Alai Selatan Kabupaten Hulu Sungai Tengah dalam keterampilan menulis teks diskusi. Hal ini dapat dibuktikan dari kemampuan siswa yang diperoleh siswa dalam menulis teks diskusi dengan menggunakan Model Pembelajaran Kooperatif Tipe Berpikir-Berpasangan-Berbagi pada akhir pelaksanaan siklus II diperoleh data hasil belajar siswa sebagai berikut.

Siklus I: Ketuntasan belajar siswa secara individual 21 orang Pada siklus I pertemuan 1 dan 2 masih ada siswa yang tidak tuntas, jadi ketuntasan belajar siswa baik secara individual maupun deskriptif pada siklus I dinyatakan tidak tuntas.

Siklus II: Ketuntasan belajar siswa secara individual 21 orang dengan ketuntasan belajar siswa secara deskriptif $100 \%$. Pada siklus II pertemuan 1 terdapat siswa tidak tuntas tetapi pada siklus II pertemuan 2 mengalami peningkatan sehingga tidak ada siswa yang tidak tuntas. Ditinjau dari indikator keberhasilan ketuntasan belajar individual, apabila siswa dapat mencapai nilai 70 atau hasil ketuntasan deskriptif $100 \%$. Jadi, ketuntasan belajar siswa, baik secara individual maupun deskriptif pada akhir siklus II dinyatakan tuntas.

2. Aktivitas guru dan siswa kelas VIII C MTsN 2 Batang Alai Selatan dalam kegiataan pembelajaran menunjukkan peningkatan. Hal ini dibuktikan bahwa pada siklus I guru cukup baik melakukan penggalian terhadap pengalaman atau pengetahuan siswa tentang menulis teks diskusi, dan guru juga cukup baik menyampaikan petunjuk secara jelas tentang bagaimana cara menulis teks diskusi yang baik. Hal ini bisa dilihat dari data hasil observasi guru pada siklus I. Namun, pada siklus II tersebut sudah terlaksana, hal ini dapat dilihat pada tabel hasil observasi kegiatan guru dalam siklus II. Peningkatan juga terjadi pada aktivitas siswa, proses belajar mengajar berjalan dengan lancar dan efektif, siswa lebih aktif dalam mengikuti pembelajaran.

3. Respons siswa kelas VIII C MTsN 2 Batang Alai Selatan Kabupaten Hulu Sungai Tengah terhadap penggunaan Model Pembelajaran Kooperatif Tipe Berpikir-Berpasangan-Berbagi dalam materi pembelajaran menulis teks diskusi, siswa antusias dan aktif dalam mengikuti pembelajaran. Meskipun model pembelajaran ini dianggap sederhana, tetapi model ini bisa membuat pembelajaran menjadi lebih menarik dan juga menyenangkan, serta juga bisa membuat siswa dapat termotivasi melalui Model Pembelajaran Kooperatif Tipe Berpikir- 
Berpasangan-Berbagi. Hal ini terbukti dari respon positif siswa kelas VIII C MTsN 2 Batang Alai Selatan Kabupaten Hulu Sungai Tengah terhadap pembelajaran menulis teks diskusi dengan menggunakan Model Pembelajaran Kooperatif Tipe Berpikir-Berpasangan-Berbagi.

B. Saran

1. Diharapkan untuk dapat menerapkan pembelajaran Kooperatif Tipe Berpikir- BerpasanganBerbagi dalam upaya meningkatkan kemampuan siswa.

2. Untuk mengetahui efektifitas pembelajaran Kooperatif tipe Berpikir-Berpasangan-Berbagi secara luas, kiranya perlu diadakan penelitian lebih lanjut agar tujuan yang diinginkan bisa tercapai dan juga harus bisa memanfaatkan model pembelajaran yang tepat.

\section{Daftar Rujukan}

Amri, Sofan. 2012. Pengembangan \& Model Pembelajaran dalam Kurikulum 2013. Jakarta: PT. Prestasi Pustakaraya.

Anita, Lie. 2004. Cooperative Learning. Jakarta: Grasindo.

Arikunto, Suharsami, 2009. Dasar-Dasar Evaluasi Pendidikan. Jakarta: Bumi Aksara.

Asrori, Mohammad. 2008. Penelitian Tindakan Kelas. Bandung: Wacana Prima

Budiningsih, Asri. 2012. Belajar dan Pembelajaran. Jakarta: Rineka Cipta.

Depdiknas. 2007. Penelitian Tindakan Kelas. Jakarta: Direktorat Jenderal Peningkatan Mutu Pendidikan dan Tenaga Kependidikan Departemen Pendidikan Nasional.

Darmadi, Hamid. 2015. Desain dan Implementasi Penelitian Tindakan Kelas (PTK). Bandung: Alfabeta.

Ibrahim, Muhsin dkk. 2000. Pembelajaran Kooperatif. Surabaya: University Press.

Paizaluddin, Ermalinda. 2016. Penelitian Tindakan Kelas. Bandung. Alfabeta.

Kementerian Pendidikan dan Kebudayaan Direktorat Pembinaan Sekolah Menengah Pertama,2015.Panduan Penilaian untuk Sekolah Menengah Pertama(SMP). Jakarta: Direktorat Jenderal Pendidikan dasar dan Menengah.

Kunandar. 2011. Langkah Mudah Penelitian Tindakan Kelas sebagai Pengembangan Profesi Guru. Jakarta: PT Raja Grafindo Persada.

Romadhona, Suci. 2009. Guru Profesional. Jakarta: Indeks.

Sanjaya, Wina. 2006. Strategi Pembelajaran Berorientasi Standar Proses Pendidikan. Jakarta: Kencana.

Sardiman. 2012. Interaksi dan Motivasi Belajar Mengajar. Jakarta: RajaGrafindo Persada. 